\title{
Factors Related to Utilization of Maternal Child Health Handbook Data by Midwives
}

\author{
Yudhy Dharmawan $^{1}$, Atha Rifqia Pradana ${ }^{1}$, Sri Winarni ${ }^{1}$ \\ ${ }^{1}$ Department of Biostatistics and Population Study, Faculty of Public Health Universitas Diponegoro, \\ Indonesia
}

\begin{tabular}{l} 
Article Info \\
\hline Article History: \\
Submitted April 2020 \\
Accepted March 2021 \\
Published July 2021 \\
\hline Keywords: \\
Data utilization, Maternal \\
Child Health Handbook, \\
Midwives \\
\hline DOI \\
https://doi.org/10.15294/ \\
ujph.v10i2.38408
\end{tabular}

\section{INTRODUCTION}

All Maternal Child Health $(\mathrm{MCH})$ healthcare data and information for all periods from pregnancy to early childhood are integrated in one handbook that named Maternal Child Health $(\mathrm{MCH})$ Handbook. In general, it is including Antenatal Care (ANC) records, labour and delivery, postpartum care, baby and childcare, immunizations, and family planning. This handbook also provides information about how mothers take care of themselves and their children (Indonesian Health Department, 2009). MCH Handbook is a book containing important information with the aim of promoting and maintaining maternal and child health as a guide for pregnancy, delivery, and childcare to facilitate care across the lifecycle (Takeuchi et al., 2016; Osaki et al., 2019).

The development of these handbook was motivated by an increase of Japan population in 1937 so the Japanese government arranged Boshi Techo which means the MCH Handbook to increase the quality of pregnant women and children. This book began to be applied en masse in Indonesia in 1998. In 2018, it has been developed in 14 countries in the world, namely Palestine, Afghanistan, Laos, Uganda, Tajikistan, Vietnam, Kenya, Myanmar, East Ti-

\footnotetext{
Correspondence Address:

Department of Biostatistics and Population Study,

Faculty of Public Health Universitas Diponegoro, Indonesia

E-mail: yudhydharmawan@gmail.com
} 
mor, including Indonesia (Nakamura, 2010; Kitabayashi et al., 2017).

Detection early in the direct cause of maternal, infant, and under-five mortality is one of the efforts that can prevent mortalities of them. Therefore, it needs a method to detect the early cause of death by doing surveillance based on society. It has done by the village community with the aim to provide information and description of health problems in the village. Implementation prevention of the incidence of morbidity and death can be done through Maternal and Child Health Management (Indonesian Health Department, 2010). The main data recording source of this surveillance is the $\mathrm{MCH}$ Handbook. Data capturing and reporting of $\mathrm{MCH}$ Local Area Monitoring (LAM) are using main data as a database (Indonesian Health Department, 2009). Health personnel included midwives record details of the services delivered in the handbook and give guidance during service provision to help clients understand its contents and encourage them to share the information with their families (Osaki et al., 2013; Yanagisawa et al., 2015).

The $\mathrm{MCH}$ data recording and reporting system do not work well. Research in Pekalongan Regency reported that just only $40 \%$ of the total pregnancies from a research sample were reported in Pregnancy, Delivery, and Infant Register completely (Burke et al., 2011). This condition is the same with the average completeness of the MCH Handbook in Temanggung Regency just only 45.29\% (Dharmawan, 2019).

$\mathrm{MCH}$ handbook must be carried at every health service attended for pregnancy, delivery, infant, and child health services as health recording for $\mathrm{MCH}$ health services management (Indonesian Health Department, 2009). Midwives can use the data in the MCH Handbook as data resources in $\mathrm{MCH}$ health program management (Indonesian Health Department, 2010). The midwives have the responsibility to make the data management in the $\mathrm{MCH}$ program in order to maintain the $\mathrm{MCH}$ program through surveillance systems use MCH Local Area Monitoring (Rani \& Hargono, 2014). Research in Bukittinggi City reported that Midwives' performance in the institutionalization of $\mathrm{MCH}$ Local Area Monitoring in unfavorable criteria was amount $62,2 \%$, but the Midwives' have good motivation and mild workload (Andriani \& Murni, 2020). These results show to us that management data in $\mathrm{MCH}$ 's program still need improvement even though $\mathrm{MCH}$ data is important to manage the $\mathrm{MCH}$ program especially for the prevention of maternal and infant mortality. Data in the MCH handbook can be used as surveillance data for the $\mathrm{MCH}$ program, also can be used by midwives to give appropriate health ser- vices for mothers and infants. At this point, the role of midwives is important to make data in the $\mathrm{MCH}$ Handbook that can be maximized in $\mathrm{MCH}$ services and program.

Theory of PRISM (Performance of Routine Information System Management) is based theory to determine the utilization of data by three factors: behavioral factors, technical factors and organizational factors. Behavioral factors in this theory are data needs, skills, attitude, and motivation. Technical factors include the complexity of the form. While the organizational factors are training, supervision, resource availability, rewards (Aqil et al., 2009). This research's objective was to know the correlation of the individual factor, technical and organizational factor toward data uses in MCH Handbook by Village Midwive.

\section{METHODS}

Data collection techniques used a survey method with a structured questionnaire instrument to describe individual factors, technical factors, organizational factors, and utilization of $\mathrm{MCH}$ Handbook data. Individual factors variable is consists i.e. perceptions of data needs, skills of $\mathrm{MCH}$ handbook data filling, motivation, and attitude. These variables measured the personal capability of the midwives included perception, skill, motivation, and the attitude of the midwives. The complexity of the $\mathrm{MCH}$ Handbook form was used to measure the technical factor. The organizational factors consist i.e. the availability of facilities perceptions, training, awards, and supervision. These variables measured the perception of midwives in facilities, training, awards, and supervision that was managed by management who supervised the midwives. All of the variables were measured by scoring in each question with the Likert Scale measurement with the lowest score 0 and the highest 4 . The population of this study is Village Midwives who work at Active Alert Village in Temanggung Regency is amount 289 midwives. The sample was taken with 31 village midwives in Active Alert Village in the working area of 3 health centers representing the urban area and rural area in Temanggung Regency. One health center with 9 midwives was representing of an urban area and two health center with 22 midwives was representing a rural area. The selection of Health Centre according to information from MCH's program manager and Active Alert Village's program manager in the District Health Office of Temanggung Regency. Active Alert Village criteria as expected midwives have taken the MCH Handbooks for surveillance in MCH Local Area Monitoring. This research used a quantitative method approach thus tabulation is used to analyze the descriptive data while genera- 
lizing analysis using the Pearson Product Moment correlation test. The percentage of index mean score against the expected total score was used to measure the variables. The percentage of an index is above $50 \%$ is means a good level. This study has received Ethical Clearance from the ethics committee Faculty of Public Health Diponegoro University number 265/EC/FKM/2016

\section{RESULTS AND DISCUSSION}

The mean of age's village midwives are 40.12 years old with age youngest 31 years old and oldest 50 years old, median value 41 and standard deviation of 5.13. Most of village midwive's education is Midwivery Academic (87,1\%). Most of the working status of the village midwive is civil servants (87.1\%), is greater than the percentage of contract working status. The tenure of the village midwive was over 10 years $(87,1 \%)$, greater than the percentage under 10-year group.

\section{Individual Factors}

Individual factors are perceptions of data needs, skills of $\mathrm{MCH}$ handbook data filling, motivation, and attitude. The percentage index mean score against the expected total score above $70 \%$. This indicates that the perception of data needs, skills of these handbook data filling, motivation, and attitude of midwives is good due to the percentage of index is above of $50 \%$. The mean score index ranges from $75.1 \%$ for Skills of MCH Handbook data filling variable up to $87.46 \%$ for the perceptions of needs data variable. This indicates midwives' perception of data needs is very high due to the percentage of index is close to $100 \%$.

The mean score index of them that we can see at Table 1 which describe score each variable and percentage of mean score against score standard for each variable. To know correlation between independent variable and dependent variable, we can see at the Table 2.

Based on the test results above indicate a significant relationship on all individual factors. There is relation of perception of data needs, data filling skills, motivation and attitudes of midwives toward the utilization of $\mathrm{MCH}$ Handbook data. The strength of the relationship is sufficient. is indicates that individual variables strongly contribute to the willingness to utilize data on this handbook. A study conducted at Kalibagor Health Center, also showed that the mother's knowledge of $\mathrm{MCH}$ Handbook was significantly related to the quality of its use (Sistiarani et al., 2014a). Other research in Semarang district also shows the Midwive's Motivation and Working Period also related to data recording quality in MCH LAM (Dharmawan et al., 2015). In line with the function of the Midwive to improve the health of pregnant women, the $\mathrm{MCH}$ Handbook is a tool for making maternal health education that can improve the health behaviors of pregnant women (Hagiwara et al., 2013; Ainiyah et al., 2018; Downer et al., 2020). Midwive's knowledge, attitude and skill also relate with completeness of $\mathrm{MCH}$ Handbook in Jepara Regency (Sarasati et al., 2016). Midwive's knowledge and attitude also significant relate with integrated management of neonatal and childhood illness (IMNCI) algorithm at neonatal services (Ira-

Table 1. Description of variable score

\begin{tabular}{|c|c|c|c|c|c|c|}
\hline Variable & $\begin{array}{l}\text { Min } \\
\text { Score }\end{array}$ & $\begin{array}{l}\text { Max } \\
\text { Score }\end{array}$ & $\begin{array}{l}\text { Mean } \\
\text { Score }\end{array}$ & SD & $\begin{array}{l}\text { Score } \\
\text { Standard }\end{array}$ & $\begin{array}{l}\text { Index of } \\
\text { mean score } \\
\text { against score } \\
\text { standard (\%) }\end{array}$ \\
\hline \multicolumn{7}{|l|}{ Individual Factor } \\
\hline Data needs & 37 & 52 & 45.48 & 4.61 & 52 & 87.46 \\
\hline $\begin{array}{l}\text { Skills of MCH Book data } \\
\text { recording }\end{array}$ & 4 & 10 & 7.51 & 1.63 & 10 & 75.1 \\
\hline Motivation & 26 & 38 & 31.87 & 2.9 & 40 & 79.67 \\
\hline Attitude & 22 & 32 & 27.03 & 2.66 & 32 & 84.46 \\
\hline \multicolumn{7}{|l|}{ Operational Factor } \\
\hline \multicolumn{7}{|l|}{ Organizational Factor } \\
\hline Training & 26 & 36 & 30.54 & 2.86 & 48 & 63.62 \\
\hline Supervision & 21 & 34 & 28.16 & 2.86 & 40 & 70.4 \\
\hline Appreciation & 22 & 36 & 28.83 & 1.29 & 36 & 66.19 \\
\hline Availability of facilities & 3 & 8 & 7.25 & 1.29 & 8 & 90.6 \\
\hline \multicolumn{7}{|l|}{ Dependent Variable } \\
\hline $\begin{array}{l}\text { Utilization of MCH Handbook } \\
\text { data }\end{array}$ & 5 & 11 & 8.64 & 1.74 & 11 & 78.54 \\
\hline
\end{tabular}


Yudhy Dharmawan, Atha Rifqia Pradana \& Sri Winarni/ Unnes Journal of Public Health 10 (2) (2021)

Table 2. Summarize of Pearson Product Moment test result

\begin{tabular}{|c|c|c|c|c|}
\hline Independent Variable & Dependent Variable & $\mathrm{r}$ & P-value & Interpretation \\
\hline \multicolumn{5}{|l|}{ Individual Factor } \\
\hline Data needs & & 0.406 & 0.024 & $\begin{array}{l}\text { Significantly, there was } \\
\text { related }\end{array}$ \\
\hline $\begin{array}{l}\text { Skills of MCH Book data } \\
\text { recording }\end{array}$ & & 0.487 & 0.005 & $\begin{array}{l}\text { Significantly, there was } \\
\text { related }\end{array}$ \\
\hline Motivation & & 0.391 & 0.030 & $\begin{array}{l}\text { Significantly, there was } \\
\text { related }\end{array}$ \\
\hline Attitude & & 0.506 & 0.004 & $\begin{array}{l}\text { Significantly, there was } \\
\text { related }\end{array}$ \\
\hline Operational Factor & Utilization of $\mathrm{MCH}$ & & & \\
\hline The complexity of forms & Hanbook data & 0.312 & 0.087 & Not Significant \\
\hline \multicolumn{5}{|l|}{ Organizational Factor } \\
\hline Training & & 0.14 & 0.943 & Not Significant \\
\hline Supervision & & 0.193 & 0.298 & Not Significant \\
\hline Appreciation & & 0.154 & 0.409 & Not Significant \\
\hline Availability of facilities & & 0.420 & 0.019 & $\begin{array}{l}\text { Significantly, there was } \\
\text { related }\end{array}$ \\
\hline
\end{tabular}

ningsih \& Azinar, 2017).

\section{Technical Factors}

The technical factors were measured by the complexity of MCH Handbook form. The mean score is 31.29 of the expected total score of 40 with SD 2.75 , so the mean score index is $78.22 \%$. This shows that midwives' perception of this form complexity is quite complicated. They feel a lot of stuffing and details that must be filled in it.

There is no correlation between the technical factor of form complexity with the used of $\mathrm{MCH}$ Handbook data. So, even though the data recorded in this Handbook is many and quite detailed and complex, it does not mean it will decrease or improve the used of data in $\mathrm{MCH}$ Handbook. Indicate from the results of this study is the perception of the complexity of the form is quite high, but the skill of officers in the MCH Handbook is also quite high. It means that the data filling skills are more correlate with the used of the MCH Handbook data. Research by Sistiarani et al. (2014), also found that the data recording in that Handbook is closely related to the mother's knowledge of that (Sistiarani, et al., 2014b). Organizational Factor

The organizational factors consist of the availability of facilities perceptions, training, awards, and supervision. The mean score index against the expected total score indicates that training variables (63.62\%) and awards (66.19\%) have the lowest score. This shows that two variables are less compared to the supervision and availability of facilities. While the availability of facilities perceived the Midwive is high (90.6\%). Midwives perceive the availability of facilities has been very good.
For organizational factors show only the availability of facilities perception associated with the utilization of $\mathrm{MCH}$ Handbook data. The better availability of facilities perception is the means the higher the utilization of $\mathrm{MCH}$ Handbooks data. While the perception of training, supervision, and awards are given by the organization is not proven relationship.

This results in line with the research in Semarang Regency which found that were related to the management performance of the midwive in the Local Area Monitoring of MCH (Dharmawan et al., 2015). Availability of facilities also have significant association with use integrated management of neonatal and childhood illness (IMNCI) algorithm by midwives (Iraningsih \& Azinar, 2017).

\section{Utilization of MCH Handbook}

For the index of data utilization scores on $\mathrm{MCH}$ Handbooks amounted to $78.54 \%$, indicating that midwives' perceptions of the use of these handbooks have been good. They are good enough to utilize this book for ANC services, counseling, monitoring of regional health status, and delivery planning. $\mathrm{MCH}$ Handbook plays a catalytic role in ensuring a continuum of maternal, newborn and child care (Aiga et al., 2015).

$\mathrm{MCH}$ Handbook is effective tools to encourage mothers in Ante Natal Care (ANC). Studies in Bangladesh, Indonesia and Mongolia show that this handbook can improve mother's knowledge and mother awareness of the importance of ANC (Osaki et al., 2013; Mori et al., 2015; Hikita et al., 2018). The data contained of it is used by midwives to make decisions about the mothers and baby health care. The 
higher data utilization in this book will greatly affect the ANC service.

Study at Sragen Regency for 34 midwives showed data completeness of MCH Handbook just only $38,2 \%$, also the use of $\mathrm{MCH}$ handbook data is $38,2 \%$, and relation both of them is significant (Cahyani et al., 2016). Another study conducted at Kalibagor Health Center shows that the quality of it is mostly good 52\% (Sistiarani et al., 2014a). While other studies that describe the quality of MCH LAM data at village midwive level in Semarang Regency showed achievement ranged between $55 \%$ to $74 \%$ (Dharmawan et al., 2015). MCH LAM data very important to be data base in Public Health Centre. Public Health Center becomes a primary data source from a health information system that plays an important role in regional health information systems (Kristian et al., 2019). Data in MCH Handbook also contribute to data quality in Public Health Centre also District Health Office.

The results of this study generally confirm that the individual factors of the midwive play a more important role in determining the utilization of data in the MCH Handbook. This is in line as stated by Tohidi, that in the Information Management Project, from three aspects of the related factors i.e. Human Resources, Employment and Organization, Human Resources is the main factor that determines its success (Tohidi, 2010). To improve the use of MCH Handbooks in addition to a personal approach that will motivate midwives, it is also necessary to use other methods such as mentoring by universities or academics, including health students as refreshing efforts to improve knowledge, skills, attitudes and midwive staff who impact on the use of it. This is like that done by the Diponegoro University which provides maternal assistance in the area around the campus by health students, and for three years the assistance can increase the ownership of these Handbook. Thus, the use of MCH Handbooks by Pregnant Mothers and Health Officers is also increasing (Dharmawan, 2017) .

\section{CONCLUSION}

Individual variable of Midwives become the main factor determining the utilization of data in $\mathrm{MCH}$ Handbook, likely perception data requirement, data filling skill, motivation, and attitude becomes the main factor of data utilization of $\mathrm{MCH}$ Handbook. Therefore, efforts to improve data utilization in this handbook should be done by increasing perception of data requirement, data filling skills, motivation and midwive attitudes. The effort can be done with a personal approach designed to improve the ability of individual midwives or midwive assistance by health students as a mentor with the goal of increasing knowledge, attitude, and motivation.

\section{ACKNOWLEDGEMENT}

I would say many thanks to Directorate of Nutrition, Ministry of Health has funded this research Project. Many thank also for Faculty of Public Health, Diponegoro University, and District Health Office Temanggung, has to give support to hold this research project.

\section{REFERENCES}

Aiga, H., Nguyen, V.D., Nguyen, C.D., Nguyen, T.T.T. \& Nguyen, L.T.P. 2015. Knowledge, Attitude and Practices: Assessing Maternal and Child Health Care Handbook Intervention in Vietnam. BMC Public Health, 16 (1): 129. DOI 10.1186/s12889-016-2788-4.

Ainiyah, N. H., Hakimi, M. \& Anjarwati, A. 2018. The Use of Maternal and Child Health (MCH) Handbook Improves Healthy Behavior of Pregnant Women. Majalah Obstetri \& Ginekologi, 25 (2): 59-62. http://repository. um-surabaya.ac.id/3851/1/jurnal The use of Maternal And Health (MCH) Handbook Improves Healthy Behavior of Pregnant Women.pdf.

Andriani, L. \& Murni, L. 2020. Motivasi dan Beban Kerja tentang Kinerja Bidan dalam Pengisian Buku KIA pada Deteksi Dini Kehamilan Resiko Tinggi di Puskesmas Kota Bukittinggi. Jurnal Riset Kebidanan Indonesia, 4 (1): 17 20. http://dx.doi.org/10.32536/jrki.v4i1.76.

Aqil, A., Lippeveld, T. \& Hozumi, D. 2009. PRISM Framework: A Paradigm Shift for Designing, Strengthening and Evaluating Routine Health Information Systems. Health Policy and Planning, 24 (3): 217-28. https://doi. org/10.1093/heapol/czp010.

Burke, L., Suswardany, D.L., Michener, K., Mazurki, S., Adair, T., Elmiyati, C. \& Rao, C. 2011. Utility of Local Health Registers in Measuring Perinatal Mortality: A Case Study in Rural Indonesia. BMC Pregnancy and Childbirth, 11 (1): 20. https://doi.org/10.1186/14712393-11-20.

Cahyani, R.N., Dharmawan, Y. \& Dharminto. 2016. Beberapa Faktor yang Berhubungan dengan Kelengkapan Pengisian dan Pemanfaatan Data pada Buku KIA oleh Bidan Desa di Kabupaten Sragen Tahun 2016. Jurnal Kesehatan Masyarakat (e-Journal) 4 (4): 238-246. https://ejournal3.undip.ac.id/index.php/ $\mathrm{jkm} /$ article/view/14035/13570.

Dharmawan, Yudhy. 2017. Pregnant Woman Mentoring by Public Health Students to Increase 
Community Participation. Advanced Science Letters, 23 (4): 3274-3276. https://doi. org/10.1166/asl.2017.9126.

Dharmawan, Yudhy. 2019. Description Data Completeness in Maternal \& Child Health $(\mathrm{MCH})$ Handbook in Temanggung Regency. Journal of Public Health for Tropical and Coastal Region, 2 (1). https://doi.org/10.14710/jphtcr. v2i1.4184.

Dharmawan, Y., Wigati, P.A. \& Dwijayanti, F. 2015. Kinerja Petugas Dalam Pencatatan Dan Pelaporan PWS KIA Di Puskesmas Duren. Jurnal Kesehatan Masyarakat (KEMAS), 10 (2): 210-17. https://doi.org/10.15294/kemas. v10i2.3383.

Downer, T., Young, J.\& McMurray, A. 2020. The Role of Antenatal Education in Promoting Maternal and Family Health Literacy. International Journal of Childbirth, 10 (1): 52-64. https:// doi.org/10.1891/ijcbirth-d-20-00012

Hagiwara, A., Ueyama, M., Ramlawi, A. \& Sawada, Y. 2013. Is the Maternal and Child Health $(\mathrm{MCH})$ Handbook Effective in Improving Health-Related Behavior? Evidence from Palestine. Journal of Public Health Policy, 34: 31-45. https://doi.org/10.1057/jphp.2012.56.

Hikita, N., Haruna, M., Matsuzaki, M., Shiraishi, M., Takehara, K., Dagvadorj, A., Sumya, N., Bavuusuren, B., Baljinnyam, P., Ota, E. \& Mori, R. 2018. Health Education Journal, 1-12. https://doi.org/10.1177/0017896917753649.

Indonesian Health Department. 2009. Petunjuk Teknis Penggunaan Buku KIA. Jakarta: Indonesian Health Department. https://libportal. jica.go.jp/library/Archive/Indonesia/219i. pdf.

Indonesian Health Department. 2010. Pedoman Pemantauan Wilayah Setempat Kesehatan Ibu Dan Anak (PWS-KIA). Jakarta: Indonesian Health Department. https://puskespemda. net/download/pedoman-pws-kia-kemenkes-2010/

Iraningsih, W. \& Azinar, M. 2017. Praktik Bidan Dalam Penggunaan Algoritma Manajemen Terpadu Bayi Muda Pada Kunjungan Neonatal. Unnes Journal of Public Health, 6 (1): 1-8. https://doi.org/10.15294/ujph.v6i1.10362.

Khuzaiyah, S., Khanifah, M. \& Chabibah, N. 2018. Evaluasi Pencatatan \& Pemanfaatan Buku Kesehatan Ibu dan Anak (KIA) oleh Bidan, Ibu dan Keluarga. Indonesian Journal of Nursing Practises, 2 (1): 22-27. https://doi. org/10.18196/ijnp.2175.

Kitabayashi, H., Chiang, C., Al-Shoaibi, A.A.A., Hirakawa, Y. \& Aoyama, A. 2017. Association between Maternal and Child Health Hand- book and Quality of Antenatal Care Services in Palestine. Maternal and Child Health Journal, 21 (12): 2161-2168. DOI 10.1007/ s10995-017-2332-x.

Kristian, S., Indrawati, F. \& Azam, M. 2019. Factors Influencing the Reporting Time of OnlineBased Recording and Reporting Systems in Public Health Center of Semarang City. Unnes Journal of Public Health, 8 (1): 29-37. https://doi.org/10.15294/ujph.v8i1.22748.

Mori, R., Yonemoto, N., Noma, H., Ochirbat, T., Barber, E., Soyolgerel, G., Nakamura, Y. \& Lkhagvasuren, O. 2015. The Maternal and Child Health (MCH) Handbook in Mongolia: A Cluster-Randomized, Controlled Trial. Edited by Susanna Esposito. PLOS ONE, 10 (4): 1-12. https://doi.org/10.1371/journal. pone. 0119772 .

Nakamura, Yasuhide. 2010. Maternal and Child Health Handbook in Japan. Japan Medical Association Journal, 53 (4): 259-265. https://www.med.or.jp/english/journal/ pdf/2010 04/259 265.pdf.

Osaki, K., Hattori, T. \& Kosen, S. 2013. The Role of Home-Based Records in the Establishment of a Continuum of Care for Mothers, Newborns, and Children in Indonesia. Global Health Action, 6 (1): 1-12. https://doi. org/10.3402/gha.v6i0.20429.

Osaki, K., Hattori, T., Toda, A., Mulati, E., Hermawan, L., Pritasari, K., Bardosono, S. \& Kosen, S. 2019. Maternal and Child Health Handbook use for maternal and child care: a cluster randomized controlled study in rural Java, Indonesia. Journal of Public Health, 41 (1): 170-182. DOI: 10.1093/pubmed/fdx175.

Rani, I. A. \& Hargono, A. 2014. Description the Activities of Recording and Reporting Maternal Health Monitoring in PWS-KIA Based on Surveillance Attributes. Jurnal Berkala Epidemiologi, 2 (1): 34-47. http://dx.doi. org/10.20473/jbe.V2I12014.34-47.

Sarasati, A.R., Mawarni, A., \& Dharmawan, Y. 2016. Hubungan Beberapa Faktor Dengan Kelengkapan Pengisian Buku Kesehatan Ibu Dan Anak Oleh Bidan Desa Di Wilayah Kerja Puskesmas Jepara Tahun 2016. Jurnal Kesehatan Masyarakat (e-Journal), 4 (4): 247-54. https://ejournal3.undip.ac.id/index.php/ $\mathrm{jkm} /$ article/view/14036.

Sistiarani, C., Gamelia, E. \& Hariyadi, B. 2014a. Analisis Kualitas Penggunaan Buku Kesehatan Ibu Dan Anak. Jurnal Kesehatan Masyarakat, 10 (1): 14-20. https://doi.org/10.15294/ kemas.v10i1.3065.

Sistiarani, C., Gamelia, E., \& Sari, D.U.P. 2014 b. 
Yudhy Dharmawan, Atha Rifqia Pradana \& Sri Winarni/ Unnes Journal of Public Health 10 (2) (2021)

Fungsi Pemanfaatan Buku KIA Terhadap Pengetahuan Kesehatan Ibu Dan Anak Pada Ibu. Jurnal Kesehatan Masyarakat Nasional, 8 (8): 353-58. http://dx.doi.org/10.21109/ kesmas.v8i8.404.

Takeuchi, J., Sakagami, Y. \& Perez, R.C. 2016. The Mother and Child Health Handbook in Japan as a Health Promotion Tool: An Overview of Its History, Contents, Use, Benefits, and Global Influence. Global Pediatric Health, 3: 1-9. https://doi.org/10.1177/2333794X16649884.

Tohidi, Hamid. 2010. Human Resources Manage- ment Main Role in Information Technology Project Management. Procedia Computer Science, 3 (2011): 925-929. https://doi. org/10.1016/j.procs.2010.12.151.

Yanagisawa, S., Soyano, A., Igarashi, H., Ura, M. \& Nakamura, Y. 2015. Effect of a Maternal and Child Health Handbook on Maternal Knowledge and Behaviour: a Community-based Controlled Trial in Rural Cambodia. Health Policy and Planning, 30 (9): 1184-1192. https://doi.org/10.1093/heapol/czu133. 